\title{
Associations of Very Low Density Lipoprotein Receptor (VLDLR) Gene Polymorphisms with Reproductive Traits in a Chinese Indigenous Chicken Breed
}

\author{
${ }^{1-3}$ D.G. Cao, ${ }^{2,3}$ Y. Zhou, ${ }^{2,3}$ Q.X. Lei, ${ }^{2,3}$ H.X. Han,${ }^{2,3}$ F.W. Li, ${ }^{2,3}$ G.M. Li, \\ ${ }^{2,3} \mathrm{Y} . \mathrm{Lu},{ }^{2,3} \mathrm{~B}$. Wu and ${ }^{1} \mathrm{Z} . \mathrm{L}$. Wang \\ ${ }^{1}$ Gansu Agricultural University, 730070 Lanzhou, Gansu, P.R. China \\ ${ }^{2}$ Academy of Agricultural Sciences, Institute of Poultry Science, \\ ${ }^{3}$ Poultry Breeding Engineering Technology Center, \\ 250023 Jinan, Shandong Province, P.R. China
}

\begin{abstract}
Chicken Very Low Density Lipoprotein Receptor $(V L D L R)$ is a physiological candidate gene for reproductive traits. The objective of the current research was to investigate the association of VLDLR Single Nucleotide Polymorphisms (SNPs) and the reproductive traits in a Chinese Indigenous chicken breed (Wenshang Luhua chicken). A total of 528 individuals were genotyped with PCR-Restriction Fragment Length Polymorphism (PCR-RFLP). As a result, an $\mathrm{A} \rightarrow \mathrm{G}$ mutation on exon 6 (A12321 G) and an $\mathrm{A} \rightarrow \mathrm{G}$ mutation on intron 17 (A13876G) were identified. In locus 12321, genotypes have significantly effect on Egg Weight at 300 days $(\mathrm{EW})$ and the chickens harboring genotype A2A2 had significantly higher $\mathrm{EW}(\mathrm{p}<0.05)$ than that of A1A1 chickens. Also the Egg Weight at First Egg (EWFE) and Egg Production at 300 days (EP) values of A2A2 chickens were higher than A1A1 chickens and A2A2 chickens had lower Living Weight at First Egg (LWFE), Living Weight at 300 days (LW) and Age at First Egg (AFE) than Al Al chickens. In locus 13876, genotypes had significantly effect on $\mathrm{EW}(\mathrm{p}<0.05)$. The $\mathrm{EW}$ values of $\mathrm{B} 2 \mathrm{~B} 2$ chickens were significantly higher than $\mathrm{B} 1 \mathrm{~B} 1$ chickens $(\mathrm{p}<0.05)$. For $\mathrm{LWFE}, \mathrm{LW}$ and $\mathrm{EP}, \mathrm{B} 2 \mathrm{~B} 2$ chickens were superior to $\mathrm{B} 1 \mathrm{~B} 1$ chickens but no significant difference between them $(p>0.05)$. Four diplotypes were constructed on the two SNPs. Significantly dominant effects of diplotypes $\mathrm{H} 1 \mathrm{H} 1$ were observed for traits $\mathrm{EW}$ whereas $\mathrm{H} 4 \mathrm{H} 4$ had a negative effect on it. Also for EWFE, LWFE, LW and EP, the H1H1 chickens were superior to $\mathrm{H} 4 \mathrm{H} 4$ chickens it maybe tell that $\mathrm{H} 1 \mathrm{H} 1$ is an advantaged diplotype for chicken reproductive traits.
\end{abstract}

Key words: Chicken, $V L D L R$ gene, PCR-RFLP, reproductive traits, locus, China

\section{INTRODUCTION}

The Very Low Density Lipoprotein Receptor (VLDLR), a member of the LDL receptor gene superfamily is an important multifunctional receptor and mediates the deposition of the Very Low Density Lipoprotein (VLDL) and Vitellogenin (VTG) which were the yolk mass components of chicken oocytes (Bujo et al., 1994; Nykjaer and Willnow, 2002).

In 1992, Takahashi and colleagues cloned a cDNA from rabbit heart that encoded a protein strikingly similar in sequence and structure to the LDLR. Expression of this cDNA in cultured cells produced a protein that bound rabbit VLDL but not LDL with high affinity. And later it was cloned in chicken, human, mouse, cattle, goose and duck. Its structure in these different species was elucidated in great detail (Bujo et al., 1994; Sakai et al.,
1994; Oka et al., 1994; Magrane et al., 1998; Wang et al., 2011). VLDLR gene encodes a protein with six functional domains: a signal sequence followed by an amino-terminal ligand-binding domain constituted by multiple cysteinerich repeats; an Epidermal Growth Factor (EGF) precursor homologous domain; an O-linked sugar domain; a transmembrane domain and a cytoplasmic domain with a FDNPVY sequence (Wyne et al., 1996; Wang et al., 2011). The chicken $V L D L R$ gene is located on the avian sex chromosome $Z$, in agreement with the sex linkage of a single-gene defect in animals that fail to reproduce because of the lack of expression of functional VLDL/VTGR (Bujo et al., 1994). It encodes an 863 amino acid protein and contains 18 exons and 17 introns in its genomic DNA sequence. Studies established that $V L D L R$ gene mediates the endocytosis of VTG and VLDL into growing chicken oocytes and plays a key role in

Corresponding Author: Y. Lu, Acadamy of Agricultural Sciences of Shandong Province, Institue of Poultry Sciences, Jiaoxiao Road 1\#, 250023 Jinan, Shandong Province, P.R. China 
control of the development of oocytes and yolk lipoprotein deposition (Barber et al., 1991; Shen et al., 1993; Hirayama et al., 2003; Takahashi et al., 2003).

Bujo et al. (1994) detected a point mutation (G/C) at position 2177 bp of the chicken VLDLR cDNA (mutation named Restricted Ovulation or RO) and showed that the mutant had a reduced egg production (Nimpf et al., 1989). Liu et al. (2000) cloned a chick 423 bp fragment using primers designed according to sequence published by orthogonal design. Zhan et al. (2009) found five SNPs in three introns (T3967G in intron 2, C8099T and A8296G in intron 7, A8839T and G9084A in intron 9) by methods of PCR-SSCP, PCR-RF-SSCP and sequencing. Results showed that VLDLR gene has important effect on the egg performance and the egg qualities in chicken. Apart from chicken, the regulation and dynamics of VTG/VLDL receptors in relation to vitellogenesis and follicle development also have been characterized in Drosophila (Schonbaum et al., 2000), trout (Rodriguez et al., 1996) white perch (Hirayama et al., 2003), Zebra finch (Han et al., 2009).

All the earlier studies has proved the important role of VLDLR gene for deposition of the yolk mass components of chicken oocytes but the associations between the SNPs of VLDLR gene and the chicken reproductive traits were researched scarcely. Markerassisted selection has become an important approach towards improving production traits in animal breeding. So, in the present study, researchers investigated the association between VLDR SNPs with reproductive traits in an indigenous chicken breed in China to identify useful single nucleotide polymorphisms for genetic selection of chicken reproductive traits.

\section{MATERIALS AND METHODS}

Animals: An indigenous breed of Wenshang Luhua chicken (WL) in Shandong province of China was used for the current study. The WL chickens were covered with barred feather and the egg production at 500 days was ranging from 200-230. A total of $528 \mathrm{WL}$ hens for this study were randomly selected form the Poultry Institute of Shandong Academy of Agricultural Science. All birds were hatched on the same day and transferred to single-gen cages at the age of 16 weeks. All birds were kept in the same laying house to minimize environmental effects. Blood samples were collected from all 528 individuals. The genomic DNA was isolated by the standard phenol/chloroform method.

Phenotypic measurements: The Egg Weight at First Egg (EWFE), Living Weight at First Egg (LWFE), Age at First Egg (AFE), Living Weight at 300 days (LW), Egg Weight at 300 days (EW) and Egg Production at 300 days (EP) were measured for each bird. Living weight was measured after $12 \mathrm{~h}$ with no access to feed. Data for EW were obtained from 528 hens on 3 days consecutively when hens were 300 days of age. The average for the 3 days was used as the value for each hen. All the experiments were complied with the requirements of the directory proposals on the Ethical Treatment of Experimental Animals of China.

Genotyping for $V L D L R$ gene polymorphisms: Sixteen pairs of primers were designed for genotyping the polymorphisms in the VLDLR gene according to the Gallus gallus VLDLR sequence (GenBank Accession No: NC-006127.2) but only two pairs of primers were polymorphic (Table 1). Primer set 1 was used to amplify the fragment $(640 \mathrm{bp}$ ) of the exon 6 of VLDLR gene, the primer set 2 was used to amplify the intron 17 of the $V L D L R$ gene. The PCR reaction was performed in a final volume of $10 \mu \mathrm{L}$ containing $0.8 \mu \mathrm{L}$ of genomic DNA $\left(2.5 \mathrm{ng} \mu \mathrm{L}^{-1}\right), 0.3 \mu \mathrm{L}$ of each primer $\left(10 \mathrm{pmol} \mu \mathrm{L}^{-1}\right), 3.6 \mu \mathrm{L}$ $\mathrm{ddH}_{2} \mathrm{O}, 5 \mu \mathrm{L}$ of $2 \times$ MasterMix (Tiangen, Beijing, China). The following PCR cycle condition was used: an initial denaturation at $94^{\circ} \mathrm{C}$ for $5 \mathrm{~min} ; 30$ cycles of $94^{\circ} \mathrm{C}$ for $20 \mathrm{sec}, 50.5^{\circ} \mathrm{C}$ (Primer set 1 ) or $50^{\circ} \mathrm{C}$ (Primer set 2) for $20 \mathrm{sec}$ and $72^{\circ} \mathrm{C}$ for $40 \mathrm{sec}$ and a final elongation at $72^{\circ} \mathrm{C}$ for $6 \mathrm{~min}$.

The fragment amplified by primer set 1 and 2 were digested with restriction enzyme $\mathrm{XbaI}$ and $\mathrm{MvaI}$ respectively, in a total volume of $15 \mu \mathrm{L}$ reaction buffer containing $8 \mu \mathrm{L} \mathrm{PCR}$ product and $5 \mathrm{U}$ of enzyme at $37^{\circ} \mathrm{C}$ overnight. The digests with the restriction enzyme were detected through $1.5 \%$ agarose gel electrophoresis, genotypes were recorded according to the band patterns. PCR products that had polymorphism as revealed by PCR-RFLP were further amplified, purified and sequenced by a commercial sequencing company (Invitrogen, Shanghai, China).

Statistical analysis: Associations of single nucleotide polymorphisms or diplotypes with reproductive traits were analyzed using the GLM procedures of SAS (SAS Inst. Inc., Cary NC). The genetic effects were analyzed by mixed procedure according to the following model:

\begin{tabular}{|c|c|c|c|}
\hline $\begin{array}{l}\text { Primer } \\
\text { set }\end{array}$ & Forward primer $\left(5^{\prime}-3{ }^{\prime}\right)$ & $\begin{array}{c}\text { Annealing } \\
\text { temprature }\left({ }^{\circ} \mathrm{C}\right)\end{array}$ & $\begin{array}{l}\text { Product } \\
\text { length (bp) }\end{array}$ \\
\hline 1 & $\begin{array}{l}\text { F: ATTGGGAATCAGGATACTAAAC } \\
\text { R: CCTACTCATTTCAGGCTCT }\end{array}$ & 50.5 & 640 \\
\hline 2 & $\begin{array}{l}\text { F: GGCTGTTCTTCCTATCTG } \\
\text { R: GGTCCCTTCTGATTGC }\end{array}$ & 50.0 & 441 \\
\hline
\end{tabular}




$$
\mathrm{Y}=\mu+\mathrm{G}+\mathrm{X}+\mathrm{e}
$$

Where:

$\mathrm{Y}=$ The dependent variable

$\mu=$ The population mean

$\mathrm{G}=$ Fixed effects of genotype or diplotype

$\mathrm{X}=$ Reproductive traits

$\mathrm{e}=$ Random error

Multiple comparisons were performed with the least squares means. Type III sum of squares was used in each F-test. Values were considered significant at $\mathrm{p}<0.05$ and presented as least square means \pm standard error means.

Haplotype reconstruction: Haplotypes were constructed based on the SNPs identified in all 528 experimental birds using the PHASE 2.0 Program. The function of this program is to reconstruct haplotypes from the population data. The genetic statuses of the subjects were expressed as the combination of two haplotypes (diplotype configuration). Genetic effects of the diplotypes were performed with the mixed model.

\section{RESULTS AND DISCUSSION}

The electrophoretic profiles of RFLP analysis of the fragment obtained from primer set 1 and 2 are shown in Fig. 1. Total of four genotypes were found and the heterozygous genotypes were not detected for both the two SNPs in the experimental population.

The homozygous genotype for each locus was further confirmed by sequencing. For locus 12321, the $\mathrm{A} \rightarrow \mathrm{G}$ mutation at position $12321 \mathrm{nt}$ (relative to GenBank Accession No: NC-006127.2) was located on the exon 6 and this SNP didn't cause amino acid change. For locus 13876 , the $\mathrm{A} \rightarrow \mathrm{G}$ mutation at position 13876 nt was located on the intron 17. The A12321G of VLDLR gene was resulted in two different gel profiles (A1A1 and A2A2) (Fig. 1a). The two genotypes (B1B1 and B2B2) of A13876G could be well recognized by two different gel profiles (Fig. 1b).

The effects of SNPs of the VLDLR gene on 6 reproductive traits were estimated and the results were shown in Table 2. In locus 12321, genotypes have significantly effect on egg weight at 300 days $(p<0.05)$ but no association was observed for the other 5 traits. In chickens but no significant difference for these five traits between them ( $>0.05$ ). In locus 13876, genotypes had significantly effect on $\mathrm{EW}(\mathrm{p}<0.05)$. The $\mathrm{EW}$ values of B2B2 chickens were significantly higher than B1B1 chickens ( $p<0.05$ ). For LWFE, LW and WP, B2B2 chickens were superior to $\mathrm{B} 1 \mathrm{~B} 1$ chickens but no significant difference between them ( $\mathrm{p}>0.05)$.

All haplotypes that were reconstructed from the 2 SNPs identified in all 528 experimental birds were shown in Table 3. Four haplotypes were identified. Haplotype-GGGG accounted for $78.41 \%$ of the observations. Four particular, the chickens harboring genotype A2A2 had significantly higher EW ( $<<0.05)$ than that of A1A1 chickens. Also the EWFE and EP values of A2A2 chickens were higher than A1A1 chickens and A2A2 chickens had lower LWFE, LW and AFE than A1A1 diplotypes were obtained from these 4 haplotypes (Table 4). The mixed model analysis indicated
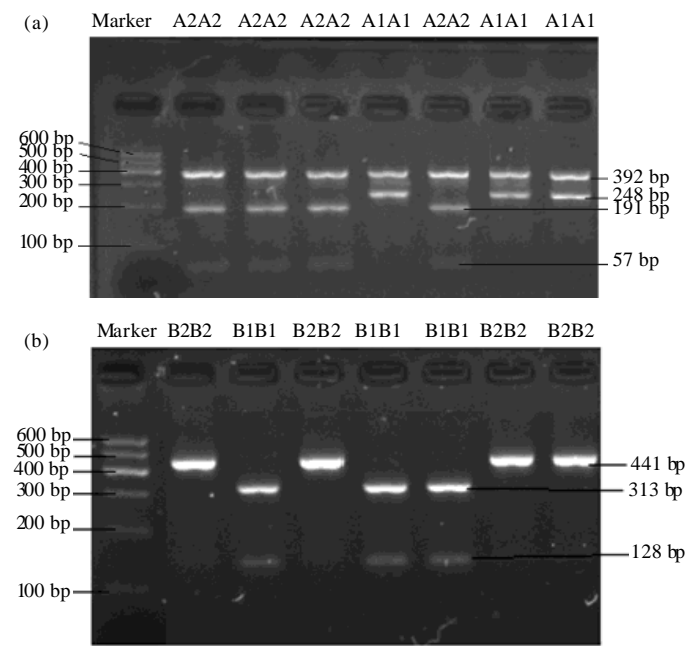

Fig. 1: The genotypes of the A12321G and A13876G single nucleotide polymorphisms in the chicken VLDLR gene; a) Genotypes of $\mathrm{A} 12321 \mathrm{G}$; b) Genotypes of A13876G

Table 2: The GLM analysis of association between the chicken reproductive traits and VLDLR gene SNPs

\begin{tabular}{|c|c|c|c|c|}
\hline \multirow[b]{2}{*}{ Traits } & \multicolumn{2}{|l|}{ Locus 12321} & \multicolumn{2}{|l|}{ Locus 13876} \\
\hline & A1A1 (109) & A2A2 (419) & B1B1 (111) & $\mathrm{B} 2 \mathrm{~B} 2(417)$ \\
\hline Egg weight at first egg (g) & $29.86 \pm 0.360$ & $29.99 \pm 0.18$ & $29.97 \pm 0.360$ & $29.96 \pm 0.18$ \\
\hline Living weight at first egg (g) & $1437.92 \pm 14.26$ & $1433.11 \pm 7.27$ & $1435.22 \pm 14.13$ & $1433.80 \pm 7.29$ \\
\hline Age at first egg (g) & $161.09 \pm 1.050$ & $161.06 \pm 0.53$ & $160.97 \pm 1.040$ & $161.10 \pm 0.54$ \\
\hline Living weight at 300 days (g) & $1496.42 \pm 18.47$ & $1493.37 \pm 9.46$ & $1495.47 \pm 18.29$ & $1493.61 \pm 9.49$ \\
\hline Egg weight at 300 days (g) & $45.86 \pm 0.350^{b}$ & $46.79 \pm 0.17^{\mathrm{a}}$ & $45.90 \pm 0.350^{\mathrm{b}}$ & $46.78 \pm 0.17^{\mathrm{a}}$ \\
\hline Egg production at 300 days & $97.86 \pm 1.870$ & $99.94 \pm 0.95$ & $97.94 \pm 1.850$ & $99.93 \pm 0.95$ \\
\hline
\end{tabular}


that there was significant association between diplotypes and reproductive traits (Table 5). Significantly dominant effects of diplotypes $\mathrm{H} 1 \mathrm{H} 1$ were observed for traits $\mathrm{EW}$ whereas $\mathrm{H} 4 \mathrm{H} 4$ had a negative effect on it. Also for EWFE, LWFE, LW and EP, the H1H1 chickens were superior to $\mathrm{H} 4 \mathrm{H} 4$ chickens it maybe tell that $\mathrm{H} 1 \mathrm{H} 1$ is an advantaged diplotype for chicken reproductive traits.

Chicken VLDLR gene is an important carrier for the vitellogenesis process and play a very important role in the process for Vitellogenin (VTG) and Very Low Density Lipoprotein (VLDL) depositing the yolk membrane. Bujo et al. (1995) described a naturally occurring mutation in a VLDLR that caused a dramatic abnormal phenotype. Hens of the mutant restricted-ovulator chicken strain carried a single mutation, lack functional oocyte receptors, were sterile and displayed severe hyperlipidemia with associated premature atherosclerosis. The mutation converted a cysteine residue into a serine resulting in an unpaired cysteine and greatly reduced expression of the mutant avian VLDLR on the oocyte surface. Extraoocytic cells in the mutant produced higher than normal amounts of a differentially spliced form of the receptor that was characteristic for somatic cells but absented from germ cells. Zhan et al. (2009) found that VLDLR gene had important effect on the age of first egg, egg production, egg weight and the percentage of yolk. Han et al. (2009) using quantitative real-time PCR measured transcriptional expression of VTG/VLDL-R mRNA in various tissues and for different stages of oocyte growth, in individual female

Table 3: Haplotypes inferred based on the 2 single nucleotide

\begin{tabular}{lccc}
\multicolumn{4}{c}{ polymorphisms in the chicken $V L D L R$ gene } \\
\hline Haplotype & $\mathrm{A}+12321 \mathrm{G}$ & $\mathrm{A}+13876 \mathrm{G}$ & Frequency (\%) \\
H1 & $\mathrm{G}$ & $\mathrm{G}$ & 78.41 \\
H2 & $\mathrm{G}$ & $\mathrm{A}$ & 0.57 \\
H3 & $\mathrm{A}$ & $\mathrm{G}$ & 0.19 \\
H4 & $\mathrm{A}$ & $\mathrm{A}$ & 20.83 \\
\hline
\end{tabular}

Table 4: Diplotypes inferred based on the 4 chicken VLDLR gene haplotypes in experimental populations

\begin{tabular}{lc}
\hline Diplotype & Frequency (\%) \\
H1H1 & 78.79 \\
H2H2 & 0.57 \\
H3H3 & 0.19 \\
H4H4 & 20.45 \\
\hline
\end{tabular}

zebra finches. They found significant temporal variation in VTG/VLDL-R expression during follicle growth with highest levels in ovary and a gradual decrease from pre-F3 to $\mathrm{F} 1$ vitellogenic follicles. Variation in ovary mRNA expression was correlated with inter-individual variation in clutch size and laying interval. Furthermore, variation in F3 follicle VTG/VLDL-R mRNA expression was correlated with inter-individual variation in egg mass and F1 follicle mass, suggesting that VTG/VLDL receptor mRNA expression is a key determinant of inter-individual variation in reproductive phenotype. Wang et al. (2011) reported that an association analysis using two completely linked SNP sites (T/C at position 2025 bp of the $\mathrm{ORF}$ and G/A in intron 13) and records from two generations demonstrated that the duck VLDLR gene was significantly associated with egg production $(\mathrm{p}<0.01)$, age of first egg $(p<0.01)$ and body weight of first egg $(\mathrm{p}<0.05)$.

In the current study, researchers screened the VLDLR SNPs in a Chinese Indigenous chicken breed by PCR-RFLP Methods. As a result, A12321 G (rs14777632) and A13876G (rs13817786) were identified. The associations between the two SNPs and egg production traits showed that the chickens harboring genotype A2A2 had significantly higher EW ( $<<0.05)$ than that of AlAl chickens. Also, the EWFE and EP values of $\mathrm{A} 2 \mathrm{~A} 2$ chickens were higher than $\mathrm{A} 1 \mathrm{~A} 1$ chickens and A2A2 chickens had lower LWFE, LW and $\mathrm{AFE}$ than A1A1 chickens. The EW values of B2B2 chickens were significantly higher than B1B1 chickens $(\mathrm{p}<0.05)$. For LWFE, LW and WP, B2B2 chickens were superior to B1B1 chickens but no significant difference between them $(p>0.05)$. The result of the association analysis were in agreement with the data reported by other researchers on chickens and were in line with the function of $V L D L R$ gene described in other species (Bujo et al., 1995; Rodriguez et al., 1996; Schonbaum et al., 2000; Hirayama et al., 2003; Han et al., 2009).

For studying both trait association (marker vs. trait) and linkage disequilibrium (marker vs. marker), haplotype or haplotype block reconstruction was more useful than marker by marker analysis and provided a practical

Table 5: Associations between diplotypes and the chicken reproductive traits

\begin{tabular}{|c|c|c|c|c|}
\hline \multirow[b]{2}{*}{ Traits } & \multicolumn{4}{|l|}{ Diplotype } \\
\hline & $\mathrm{H} 1 \mathrm{H} 1$ & $\mathrm{H} 2 \mathrm{H} 2$ & $\mathrm{H} 3 \mathrm{H} 3$ & $\mathrm{H} 4 \mathrm{H} 4$ \\
\hline Egg weight at first egg (g) & $29.97 \pm 0.18$ & $32.33 \pm 2.1200$ & $26.00 \pm 3.6800$ & $29.90 \pm 0.360$ \\
\hline Living weight at first egg (g) & $1433.60 \pm 7.31$ & $1368.33 \pm 83.680$ & $1512.00 \pm 144.95$ & $1437.19 \pm 14.35$ \\
\hline Age at first egg $(\mathrm{g})$ & $161.08 \pm 0.54$ & $159.33 \pm 6.2100$ & $169.00 \pm 10.760$ & $161.01 \pm 1.060$ \\
\hline Living weight at 300 days (g) & $1494.23 \pm 9.49$ & $1385.33 \pm 106.58$ & $1260.00 \pm 184.61$ & $1498.80 \pm 18.55$ \\
\hline Egg weight at 300 days $(\mathrm{g})^{*}$ & $46.78 \pm 0.17^{\mathrm{a}}$ & $47.76 \pm 1.9700^{\mathrm{ab}}$ & $47.85 \pm 3.4100^{\mathrm{ab}}$ & $45.84 \pm 0.350^{b}$ \\
\hline Egg production at 300 days & $99.91 \pm 0.95$ & $104.33 \pm 10.760$ & $110.00 \pm 18.640$ & $97.74 \pm 1.880$ \\
\hline
\end{tabular}


solution to resolve these problems (Daly et al., 2001; Zhang et al., 2002). The associations of haplotypes with phenotypic traits were more accurate than those of single SNP (Zhang et al., 2004, 2005; Zhou et al., 2010, 2012). In this study, based on 2 SNPs, four haplotypes were identified. Haplotype-GGGG accounted for $78.41 \%$ of the observations. Four diplotypes were obtained from these 4 haplotypes. Correlation analysis results showed that significantly dominant effects of diplotypes $\mathrm{H} 1 \mathrm{H} 1$ were observed for traits EW whereas $\mathrm{H} 4 \mathrm{H} 4$ had a negative effect on it. Also for EWFE, LWFE, LW and EP, the H1H1 chickens were superior to $\mathrm{H} 4 \mathrm{H} 4$ chickens and it indicated that $\mathrm{H} 1 \mathrm{H1}$ is an advantaged diplotype for chicken reproductive traits.

\section{CONCLUSION}

In this syudy, the $\mathrm{A} \rightarrow \mathrm{G}$ mutation at position $12321 \mathrm{nt}$ in exon 6 and the $\mathrm{A} \rightarrow \mathrm{G}$ mutation at position $13876 \mathrm{nt}$ in intron 17 were identified. Each SNP was significantly associated with reproductive traits in chickens. The results once again confirmed that the $V L D L R$ gene may have a major effect on egg production traits in chickens. The VLDLR gene can be a useful marker for molecular marker-assisted selection of reproductive traits in chickens. In order to make the selection schemes more applicable it would be necessary to further definitions of the effect of VLDLR variants on chicken reproductive traits and confirmation of their inheritance in different genetic populations. In particular, this study laid the foundation for the innovative use of local chicken breeds in China.

\section{ACKNOWLEDGEMENTS}

The current research was supported by the fund from: Major Agricultural Stock Breeding Project of Shandong Province (2008LZ015-05); Chinese Shandong Province Nature Fund (ZR2009DM004) and Major Agricultural Stock Breeding Project of Shandong Province (2011LZ15). Wang, Z.L. and Y. Lu contributed equally to this research.

\section{REFERENCES}

Barber, D.L., E.J. Sanders, R. Aebersold and W.J. Schneider, 1991. The receptor for yolk lipoprotein deposition in the chicken oocyte. J. Biol. Chem., 266: 18761-18770.

Bujo, H., M. Hermann, M.O. Kaderli, L. Jacobsen and S. Sugawara et al., 1994. Chicken oocyte growth is mediated by an eight ligand binding repeat member of the LDL receptor family. EMBO J., 13: $5165-5175$.
Bujo, H., T.Yamamoto, K. Hayashi, M. Hermann, J. Nimpf and W.J. Schneider, 1995. Mutant oocytic low density lipoprotein receptor gene family member causes atherosclerosis and female sterility. Proc. National Acad. Sci. Am., 92: 9905-9909.

Daly, M.J., J.D. Rioux, S.F. Schaffner, T.J. Hudson and ES. Lander, 2001. High-resolution haplotype structure in the human genome. Nat. Genet., 29: 229-232.

Han, D., N.H. Haunerland and T.D. Williams, 2009. Variation in yolk precursor receptor mRNA expression is a key determinant of reproductive phenotype in the zebra finch (Taeniopygia guttata). J. Exp. Biol., 212: 1277-1283.

Hirayama, S., T.M. Bajari, J. Nimpf and W.J. Schneider, 2003. Receptor-mediated chicken oocyte growth: Differential expression of endophilin isoforms in developing follicles. Biol. Reprod., 68: $1850-1860$.

Liu, X.Q., Y.Z. Gong, C.Z. Yu and S.X. Shen, 2000. Amplification, cloning and identification of an OVR gene fragment. China Poult., 22: 6-7.

Magrane, J., M. Reina, R. Pagan, L. Luna and R.P. Casaroli-M arano et al., 1998. Bovine aortic endothelial cells express a variant of the very low density lipoprotein receptor that lacks the O-linked sugar domain. J. Lipid Res., 39: 2172-2181.

Nimpf, J., M.J. Radosavljevic and W.J. Schneider, 1989. Oocytes from the restricted ovulator hen lack receptor for very low density lipoprotein. J. Biol. Chem., 264: 1393-1398.

Nykjaer, A. and T.E. Willnow, 2002. The low density lipoprotein receptor gene family: A cellular Swiss army knife? Trends Cell Biol., 12: 273-280.

Oka, K., K. Ishimura-Oka, M.I. Chu, M. Sullivan, J. Krushkal, W.H. Li and L. Chan, 1994. Mouse very low density lipoprotein receptor $(V L D L R)$ cDNA cloning, tissue-specific expression and evolutionary relationship with the low-density-lipoprotein receptor. Eur. J. Biochem., 224: 975-982.

Rodriguez, J.N., E. Bon and F.L. Menn, 1996. Vitellogenin receptors during vitellogenesis in the rainbow trout (Oncorhynchus mykiss). J. Exp. Zool., 274: 163-170.

Sakai, J., A. Hoshino, S. Takahashi, Y. Miura, H. Ishiii, H. Suzuki, Y. Kawarabayasi and T. Yamamoyo, 1994. Structure, chromosome location and expression of the human very low density lipoprotein receptor gene. J. Biol. Chem., 269: 2173-2182.

Schonbaum, C.P., J.J. Perrino and A.P. Mahowald, 2000. Regulation of the vitellogenin receptor during Drosophila melanogaster oogenesis. Mol. Biol. Cell, 11: 511-521. 
Shen, X., E. Steyrer, H. Retzek, E.J. Sanders and W.J. Schneider, 1993. Chicken oocyte growth: Receptor mediated yolk deposition. Cell Tissue Res., 272: 459-471.

Takahashi, S., J. Sakai, T. Fujino, I. Miyamori and T.T. Yamamoto, 2003. The Very Low Sensity Lipoprotein (VLDL) receptor-a peripheral lipoprotein receptor for remnant lipoproteins into fatty acid active tissues. Mol. Cell. Biochem., 248: 121-127.

Wang, C., S.J. Li, W.H. Yu, Q.W. Xin and C. Liet al., 2011. Cloning and expression profiling of the $V L D L R$ gene associated with egg performance in duck (Anas platyrhynchos). Genet. Sel. Evol., 43: 29-29.

Wyne, K.L., R.K. Patha, M.C. Seabra and H.H. Hobbs, 1996. Expression of the VLDL receptor in endothelial cells. Arteriosclerosis, Thrombosis Vascular Biol., 16: 407-415.

Zhan, H.Q., Y.P. Feng, S.X. Shen, P. Gong, X.L. Peng, S.J. Li and Y.C. Gong, 2009. Polymorphisms of chicken Occyte Vitellogenesis Receptor gene (OVR) and association with egg traits of chickens. J. Agric. Biotechnol., 17: 967-971.
Zhang, K., P. Calabrese, M. Nordborg and F. Sun, 2002. Haplotype block structure and its applications to association studies: Power and study designs. Am. J. Human Genet., 71: 1386-1394.

Zhang, K., Z. Qin, T. Chen, J.S. Liu, M.S. Waterman and F.Z. Sun, 2005. HapBlock: Haplotype block partitioning and tag SNP selection software using a set of dynamic programming algorithms. Bioinformatics, 21: 131-134.

Zhang, W.H., A. Collins and N.E. Morton, 2004. Does haplotype diversity predict power for association mapping of disease susceptibility. Human Genet., 115: 157-164.

Zhou, Y., D.G. Cao, Q.X. Lei, H.X. Han, F.W. Li, G.M. Li and B.H. Huang, 2012. Associations of melanocortin-4 receptor (MC4R) gene single nucleotide polymorphisms with carcass traits in a synthetic broiler line. J. Anim. Vet. Adv., 11: 13-19.

Zhou, Y., Y. Liu, X. Jiang, H. Du, X. Li and Q. Zhu, 2010. Polymorphism of chicken myocyte-specific enhancer-binding factor $2 \mathrm{~A}$ gene and its association with chicken carcass traits. Mol. Biol. Rep., 371: $587-594$. 